Article

\title{
Combining and Balancing Work and Study on the Eastern Border of Europe
}

\author{
Gabriella Pusztai and Zsófia Kocsis * (D) \\ Institute of Educational Studies and Cultural Management, University of Debrecen, 4032 Debrecen, Hungary; \\ pusztai.gabriella@arts.unideb.hu \\ * Correspondence: zsofikocsis6@gmail.com
}

Received: 2 May 2019; Accepted: 11 June 2019; Published: 19 June 2019

\begin{abstract}
There is a vast amount of research in many countries on what motivates full-time students to enter the labor market, and how this affects their future employment, but these phenomena are hardly ever examined from the perspective of university faculties or student job centers, i.e., the other two parties involved. The novelty of this research is that we took into account students', faculty members' and student job centers' perspectives. This article reports on a study that investigated the social and organizational factors of student employment in Hungary. Fieldwork in 16 student job centers and a content analysis of 23 interviews with students and 7 interviews with faculty members were conducted. The qualitative data collected provides detailed information on how students find jobs and combine work with study. According to student perceptions, term-time work contributes to their employability. This study has also identified factors that might lead to an increased dropout rate. Furthermore, research results suggest that the conservative structure of higher education is incapable of reacting to new social challenges.
\end{abstract}

Keywords: term-time work; combining work and study; student employment; higher education; Hungary

\section{Introduction}

The growth in student employment is usually associated with changes that European higher education has been undergoing over the past 50 years. This is partly due to the fact that many low-status students, on a low income, have been admitted into universities, and partly due to the introduction of some more practical forms of training in addition to the traditional theoretical training, which has led to the consolidation of the relationship between work experience and study. Over the last decades, the level of employment among university students has seen an increase. Students are allocating more time and resources to incorporate work into their daily routines. The Eurostudent VI study, which examines tertiary students in 28 European countries, states that $39 \%$ of students in Hungary work regularly during the semester (Masevičiūtè et al. 2018). In recent decades, higher education student employment figures have increased globally. On average in Europe, over 50\% of 24-year-old students do some form of paid work during the academic year (Moreau and Leathwood 2006; Riggert et al. 2006). It was not until the turn of the millennium that the expansion of higher education reached Hungary; consequently, student employment became widespread somewhat later there compared to Western Europe (Canny 2002; Pusztai 2014). Hungary still seems to be lagging behind Western Europe or even Russia in this respect (Roshchin and Rudakov 2017). Although two thirds of full-time students have their studies partly or entirely funded by the state, the relative prevalence of student employment has increased in recent years. Student surveys reveal that higher education imposes a heavy burden on family budgets, even though the number of tuition-paying students is rather low. The total cost of textbooks, electronic devices, clothing, accommodation and living expenses, as well as 
entertainment, sport activities and, socializing are beyond what even middle-class families can easily afford, not to mention families of low socioeconomic status or families with many children (Pusztai 2015). As student attrition rate is rather high in Hungary-36-38\% for bachelor students, 14-17\% for master's degree students (Derényi 2015), and over 50\% in doctoral schools (Pusztai and Kozma 2009)_one might suspect that intensive paid work may contribute to poor academic performance and procrastination, and even to students dropping out of their degree programs. The negative effects of work on students' lives were also examined based on Eurostudent VI. Approximately 7\% of students have discontinued their studies for at least one year. Data in Hungary corresponds to the EU average in this respect. In Hungary, 29\% of students taking a break in their studies cited employment as one of the reasons (Masevičiūtè et al. 2018).

The present study investigates student employment in two higher education institutions in the most disadvantaged-i.e., the North-Eastern-region of Hungary. As in other countries, regional analysis is important in Hungary, since regional variance in the dynamics of the labor market may influence job opportunities for students (Gouvias and Vitsilakis-Soroniatis 2005). While in the capital and in Western Hungary, employment opportunities abound, in the region surveyed, unemployment was high even among the working age population until the state intervened as a public employer. Nonetheless, almost half of all students involved in our research were able to find work in the region. While our study conducted in 2005 found that $12 \%$ of students worked regularly, according to data from 2015 , this percentage has increased to $44-50 \%$ of undergraduates at the two universities under scrutiny (Kocsis 2017a, Kóródi 2007).

\section{Theoretical Considerations and Previous Research Findings}

One of the main research aims in this area is to identify the motivating factors for students combining work and study. Apparently, students have a number of different reasons, ranging from the increase of financial or human capital to boosting their CVs with work experience (Becker 1994; Bocsi et al. 2017; Riggert et al. 2006). Another question is what individual, social, demographic and cultural factors and which components of the institutional environment, promote or upset the balance between study and work. What exactly is the maximum workload before a risk of attrition arises? The effect of students' term-time employment on academic performance depends on employment intensity (hours worked per week), which correlates with the amount of financial support from students' families (Riggert et al. 2006; Roshchin and Rudakov 2017). As a result vulnerable student groups emerge, which require political protection (Baffoe-Bonnie and Golden 2007). The influence of term-time work on student outcomes also depends on whether students are employed off or on campus (Astin 1993). If they are employed off campus, over $25 \mathrm{~h}$ of work per week can have a negative influence on academic performance, while in case of on campus employment, it was found that employment has the potential to increase student participation in, and integration into university life (Pascarella et al. 1998).

Another important question is whether the students' job is related to their field of study. Student work in Hungary is usually not related to the students' field of study; however, it can undoubtedly be seen by employers as a sign of determination and diligence. Many forms of student employment present the potential to enhance student outcomes, and reduce levels of inequality (Perna 2012; Pusztai 2011). Employers have attested to the fact that student employment has a positive effect on knowledge, skills, and future employment opportunities (Hovdhaugen 2015; Pascarella and Terenzini 2005). In undertaking term-time employment, students are likely to acquire goal-oriented attitudes, moral values and a sense of responsibility which may transfer into later work environments. One possible short-term outcome is that students learn to compensate for the reduced amount of time remaining for their studies, or use the time at their disposal more efficiently. Working habits can lead to positive results, especially when the job is related to one's career path (Pascarella et al. 1998). The affective outcomes of higher education are equally important to cognitive outcomes. Perceived employability-i.e., the assessment of one's prospects after graduation-can influence levels of incentive and persistence, as well as future employment opportunities (Kasler et al. 2017). According to Perna, student employment 
plays a role in shaping students' identity, enhancing academic engagement and self-regulatory skills, and yielding a positive effect on the person's future success on the labor market (Perna 2012). In light of this, part-time student employment underpins the idea that a workplace is essentially a place for learning. In reference to the positive effect of student work, Pusser (2012) makes a distinction between student employment and student work. The purpose of the former is remuneration, whereas the latter serves personal development, which adds extra value to student work.

On the other hand, investigating the effects of combining work and study on academic performance we come to the conclusion that student employment can also be interpreted as a risk factor reinforcing social inequalities (Darmody and Smyth 2008). This affects students from low-status families. They risk dropping out as their job hinders integration into mainstream university culture (Perna 2012; Riggert et al. 2006). Employment is a double-edged sword. On the one hand, it can hinder students' academic performance, while, on the other hand, entering the labor market can have long-term positive effects. On the whole, it seems that student work is characterized by diversity and contradiction at the same time; consequently it is worth examining it more closely. In our study we reveal that the conservative structure of higher education is incapable of reacting to the new social challenges emerging from the changes in students', as well as labor market expectations. Instead of traditional theoretical training there is a need for a more practical, competence-based higher education.

\section{Methods}

To provide a comprehensive picture of student work and its impact, we have conducted semi-structured individual interviews with 23 students and 7 professors at the two institutions (University of Debrecen, University of Nyíregyháza). We used the snowball sampling technique to select students with regular paid jobs. Since our sample was not representative, and we focused on students from only two institutions, we could not make generalizations about the relationship between student employment and the interviewees' social status. Previous studies carried out at our research center (Pusztai 2011, 2014) confirmed that students in this region come from lower social status families in which the highest grade level completed by parents is secondary school. Comparing the two institutions, students at the University of Nyíregyháza come from somewhat lower status families, mainly from a rural environment (Pusztai 2015). Although we used snowball sampling, the proportion of children in middle and upper secondary schools was the same as the student composition of the region. We used semi-structured interviews, exploring particular themes in order to reveal features of student employment. This method allowed us to analyze the interviews from different points of view. Using Nagy's (2006) method we recorded the interviews and then divided the transcript into short chunks. We used a first code system and marked the topic of the units. Student interviews were analyzed considering the following aspects: Family background, financial situation, students' opinions, past and present jobs, relationship between work and study. Relying on our previous experience and the literature in the field, we attempted to interpret and summarize the interviews.

Since the two cities are not only higher education centers but also provide work opportunities for students from the region, including commuters, we conducted semi-structured interviews with the staff of job centers.

Interviews with faculty members at the two universities revealed yet another aspect of student employment. The seven academics interviewed belonged to faculties with the highest number of students, namely teacher training and social sciences, where the ratio of working students was also the highest. Masevičiūte et al. (2018) found that students majoring in social sciences, arts and humanities work more during their studies. We assumed that, given the nature of the training program, the academics of these faculties are more familiar with their students. They have more opportunities to become familiar with the students' family background, the problems they face, and even their work habits. Faculty members were asked about their evaluation of student employment, their experiences with students who work and ways of dealing with students' problems arising from employment. 


\section{Results}

\subsection{Student Jobs from the Student Job Centers's Point of View}

As the expansion of higher education led to a steep rise in the number of students who work, regulation regarding student work was implemented in the 2000s in order to avoid tax evasion and student exploitation (Gáti and Róbert 2011; Kocsis 2017a; Kóródi 2007). However, these regulations failed to provide for this special employee status. In order to reduce youth unemployment and facilitate flexible career launch, in 2011 the government, in conformity with higher education law and labor law, laid down the rules and regulations for the operation of student job centers. These regulations are still in force today. Members of job centers are full-time students and higher education institutions and their aim is to provide a framework for legal, paid work for students. When offered a job, students sign a contract with the job center.

"If students want to become members, they have to pay a membership fee of 1000 Forints (365 CHF) for registration. The amount of the fee and the timing of payment are determined by each center. If students choose to leave the center, the membership fee is refunded." (Student job center representative)

On registration an account is created, which students can use to keep track of work-related information.

"On registration applicants can specify the type of work they are interested in, their work experience,

language proficiency, as well as their availability." (Student job center representative)

Members must be over 18 years old, full time active or passive (taking a semester leave) students. In conformity with student employment tax law, job centers register students with the National Tax and Customs Administration to ensure legal employment. Students are to pay a personal income tax of $15 \%$, which is to be deducted and paid by student job centers. Centers are coordinated by regional managers and various tasks are supervised by project managers. They are the ones who see to students' needs and help them with the paperwork. Working time, minimum wages and working conditions for students are regulated by law. Previous research (Kocsis 2017a, 2017b) has shown that the majority of students in Hungary find work mainly through job centers.

There are some centers that focus on specific jobs while others offer a variety of job opportunities. The most common vacancies are for the positions of cashier, office assistant, marketing assistant, call center representative, as well as direct marketing and market research assistant. The most common job offers requiring manual labor are production worker, warehouse or packaging worker in canning factories or cold storage warehouses, printing press helper, restaurant helper, as well as newspaper and leaflet distributor. There are also job offers which require professional expertise and a good command of English, as well as knowledge of at least one other language. Some of these positions are software developer, customer support agent or multilingual customer service agent providing help to customers in a foreign language over the phone or by email. The average hourly wage paid for these jobs is over 1000 HUF (3.62 CHF).

"Students prefer bartender or hostess jobs because they usually have to work at an event or concert, and this is not boring or monotonous. Of course, they do not go there for fun; however, they still get the change to attend such event. Many students have worked at festivals, which they definitely enjoyed." (Student job center representative)

On the whole, student job centers do their best to offer a wide range of services to students who are looking for work. Centers support and guide registered members through the job search process in order to ensure a well-paid job in conformity with national laws and regulations. The staff is flexible, ready to help and the place is characterized by a youthful atmosphere. These organizations cope well with situations when students decide to quit a job, since they can easily find replacements. In Hungary, there are national student job centers with offices in several university towns, and there are 
also local endeavors. In Nyíregyháza, a town with 100,000 inhabitants, there are 6 student job centers, while in Debrecen, where the number of inhabitants is double compared to Nyíregyháza, there are 10 student job centers. The centers under scrutiny are located either on campus or its surroundings, or in the city center. Seeking help at student job centers has its advantages; however, these organizations mainly offer student jobs that are rarely related to the students' field of study. In our research $80 \%$ of interviewees did a job that was not related to their study, such as hostess, bartender, or waiter.

\subsection{Student Voices on Their Jobs}

Student employment is a complex phenomenon. Its emergence can be attributed to various factors and its impact can manifest in various ways. By analyzing student interviews, we attempted to identify individual differences and peculiarities in students' work- related habits. We have also looked into different factors and motivations relating to employment.

The median age of the interviewees was 22. Our sample contained 15 female and 8 male students, a ratio equivalent to the regional male-female student ratio. Among respondents from the regional research institute, the University of Debrecen, there were biologists, lawyers, IT engineers, as well as students enrolled in master's degree program in hydrobiology. Among students at University of Nyíregyháza, which offers a narrower range of programs, there were primary teacher trainees, nursery and kindergarten teacher trainees, students of computer science, and students of mechanical engineering in agriculture and the food industry.

\subsubsection{Social Background}

The family background of the interviewees painted a very colorful picture: The parents of most students had a secondary or lower level of education (skilled worker). A quarter of the students had parents with higher education degrees, and the same proportions had low-educated parents. Previous research in the field shows that students who came from a lower-class background were more likely to work given their financial difficulties (Bocsi et al. 2018; Gáti and Róbert 2011). These students were usually not motivated by gaining work experience.

According to students' responses their family members are supportive. Students are in a good relationship with their parents, they strive to spend time together; however their employment often makes this difficult. All respondents aspire to become financially independent. There were only a few students who had already succeeded in this. Most of the students still lived with their parents but they strived to be as light a burden for their parents as possible. Some of the students were in a financial situation that allowed them to support their families financially. Most of the students did not receive an allowance from their parents, and those who did, received between $5000 \mathrm{HUF}$ (18 CHF) and 45,000 HUF (163 CHF) depending upon the means of the family and the students' expenses.

"Each month I pay my accommodation fee, local bus pass and gym membership out of the pocket. The accommodation fee is the most significant amount. I cover all major expenses resulting from my lifestyle, which amounts to 30-35,000 HUF per month. I also spend 20-30,000 HUF on shopping, entertainment and the like. I am financially independent." (male student from the University of Nyíregyháza)

"The rent (65,000 HUF), phone bill (12,000 HUF) and transport (9500 HUF) are recurring monthly expenses, and so is money spent on cigarette and food. I need roughly 80,000 HUF a month (290 CHF)." (female student, University of Debrecen)

Students usually spend their earnings on rent or student hostel accommodation fees, utility and phone bills, clothing and food, sometimes on tuition fees. One of the respondents spent the earning on entertainment. On balance, respondents needed an average of 40,000-70,000 HUF (144-254 CHF) per month to cover their daily expenses. They could not save considerable amounts of money in the long run. 
The interviewees were not selected using probability sampling; consequently conclusions cannot be drawn with respect to which social groups are most vulnerable to the negative effects of work. For students who came from a lower-class background, employment was not a free choice, but rather a must, given their financial difficulties. The more unfavorable the family background, the more compelled students are to focus on work rather than study. The role of the family; however, is not limited to that of financial support. Family values, norms, and coping strategies are also of great significance. According to students, their families do not have a direct influence on their employment or their decisions. However, the indirect influence of the family surfaces in many ways during students' employment and studies, some of these are: Material insecurity, work values, and commitment to studying.

\subsubsection{Students' Opinions of Job Centers}

Most students found their jobs with the help of student job centers, and they think this has both advantages and disadvantages. Students got in contact with their employers through the intermediary of job centers, and this is also how they receive their wages. In return, students have to pay an annual membership fee, which might be a burden for those who do not receive any financial support, and in addition, they have to find the necessary resources that would allow them to take up a job. As regards services offered by student job centers, students noticed significant differences in hourly wages, timing of payments, the quality of the jobs offered, the degree of organization, the quality of administration, as well as the helpfulness of the staff. "Some centers deliberately keep wages low and exert influence over candidate selection." (male student, University of Debrecen). This, of course, is not characteristic of all student job centers. Most students managed to find a job center they were satisfied with. Those who encountered problems either registered with another center or several others in order to ensure a favorable position as regards employment.

\subsubsection{Previous and Current Jobs}

Interview questions focused on students' current jobs, the nature of their job, as well as payment and work experiences. Of all respondents, 21 were working through the intermediary of student job centers, 2 students found their jobs with the contribution of the university and acquaintances, and only 6 students had jobs related to their study. These 6 students were more satisfied with their jobs, their time management and achievements. Their job had a positive effect on their lives, providing an opportunity to gain practical work experience and get to know how companies operate. Furthermore, their jobs provided an opportunity for building professional networks.

The interviews revealed a certain hierarchy of student jobs, which most of the respondents had gone through. The jobs with the lowest prestige were the ones in factories and department stores. One step higher were seasonal jobs in catering (bartender, hostess), while the jobs with the highest prestige were the ones requiring language proficiency and other expertise. Students working jobs that were not related to their study usually do not include these on their $\mathrm{CV}$, especially if they have done manual labor (Markos 2014).

"I have had a lot of jobs, I can't enumerate them. I worked in a supermarket, a printing press, and I also worked as a hostess at various events. The work I have done was not related to my study." (female student, University of Debrecen)

"I worked as a hostess, and I work for the same employer every summer. I pick raspberries every day from dawn till $5 o^{\prime}$ clock... " (female student, University of Nyíregyháza)

Respondents were paid the minimum wages per hour stipulated by law (639 HUF $=2.32 \mathrm{CHF}$ ). Students who earned more had jobs requiring extra stamina (e.g., working night shifts) or professional experience, and they received bonuses or allowances. Respondents worked an average of $16 \mathrm{~h}$ per week in an uneven distribution. Some of the students worked one day per week, for less than $8 \mathrm{~h}$, 
while others worked $8 \mathrm{~h}$ shifts, 3-4 days a week. There were students who worked $8 \mathrm{~h}$ each day; however, the work was related to their study, and could be done from home. These students had an opportunity for professional development and for gaining valuable work experience. They did not feel that their jobs took away time from studying, and they benefited from their work not only financially but also professionally. All things considered, the main determining factor in choosing a job was the amount of money it paid.

\subsubsection{The Relationship between Work and Study}

If students have jobs related to their study, they are more likely to gain practical skills and experience not offered by universities. This advantage is particularly important when they enter the labor market. In general, students of IT, engineering, medicine and language studies will find work in their field. According to Kocsis (2017a), only 20\% of students have jobs related to their field of study. Students find it difficult to balance work and study. Some of them managed to find a job related to their study, contributing to their professional development, while other students only gained work experience in a job not related to their study.

"I work as an accountant for the church, I can work from anywhere. I have to be present at church once a month for the end-of-the month accounting procedures. I earn $639 \mathrm{HUF}$ per hour (2.32 CHF), and I think it's an ideal student job. I work alone and my mother is my boss." (female student, University of Debrecen)

"Network management skills and the operation of UNIX-based systems are indispensable for my work, as well as a good command of English. I may as well be on duty for a week, which means I have to be available on the phone round the clock. If I get a call, I have to get my laptop wherever I am and solve the problem. At least I have a flexible job and sometimes I can take work home. Once I ended up working during a lecture." (male student, University of Debrecen)

Examining the relationship between study and work, we found that one-tenth of the students who are employed had jobs related to their study. In our case this meant 6 students, while the rest of the respondents had jobs that are typical for students.

"I work in a supermarket. I work 1 to 3 times a week, and in the summer almost every day. I work 8 or 8.5 h a day. The hourly wage is 811 HUF (2.94 CHF), on Sunday it is 1065 HUF (3.86 CHF). My work does not require special qualifications. If you can read, you can work... " (male student, University of Debrecen)

\subsubsection{The Negative Impact of Student Employment}

Student employment can often be interpreted as a risk factor that strengthens social inequalities and also increases the risk of dropping out by keeping students away from integrating into the academic culture and community (Darmody and Smyth 2008; Perna 2012; Riggert et al. 2006). Based on data from McCoy and Smyth (2004) the dropout rate is higher among students who have a long-term job. Long working hours may have unpleasant consequences on the individuals' well-being, including fatigue or disorders caused by stress, injuries, and the lack of balance between work and life (Baffoe-Bonnie and Golden 2007).

All respondents were aware of the importance of working hours. Every hour spent working meant an hour less spent studying. Our interviewees find it difficult to establish a connection between their work and their study. Two thirds of the students had jobs totally unrelated to their field of study. Balancing study and work posed a great challenge for them.

"I'll never forget how tired I was when I worked on the night shift. I finished work at six, went home, had a shower and breakfast, and went to class at 8 because I couldn't skip classes. I was almost trembling with fatigue, but I had no other choice as I was short of money and couldn't work during the day because of my classes." (female student, University of Nyíregyháza) 
Even though achieving good results at university was a priority, many students needed a job. The interviews made it clear that it was not easy to find work that suited one's schedule and provided adequate income at the same time.

"I definitely study less, and work occupies my mind outside working hours as well. I worry about whether I got something wrong, about what I will answer N., what the solution could be etc. That's why I concentrate on my studies far less." (female student, University of Debrecen)

Students who had a job considered the decrease in the amount of time spent studying as an inherent risk factor, which could only be compensated for by a certain degree of financial return. They tried not to let work have a negative influence on their studies; however, they did not always succeed in this as they often felt tired and unable to concentrate. These setbacks were mainly reported by students who worked night shifts.

In spite of the difficulties, respondents did not wish to quit work; on the contrary, they were determined to remain employed until graduation, not only to make a living but also to gain experience. Even if their job was not related to their study, students were satisfied to gain experience. They experienced team work, learned how to write a CV, and their jobs had a positive impact on their time management and communication skills. Students' opinion on the positive effects of work was consistent with the results of previous research (Riggert et al. 2006; Darmody and Smyth 2008; Perna 2012; Stiburek et al. 2017). As regards future plans, they unanimously stated that they would like to work in their professions after graduation. Some of the students planned to continue their studies and enroll in a master's degree program. Based on their experiences and visions, they set ambitious goals regarding their future jobs, with the minimal expectations of a proper income, professional development and flexible work schedule.

\subsection{Student Jobs from the Academics' Point of View}

Interviews with faculty members as part of our complex research on students and student job centers shed new light on student employment. We interviewed staff from faculties with a relatively high proportion of students registered with student job centers. The interview questions focused mainly on academics' evaluation of student work, and the relationship between students and academics. Faculty members also expressed their views on how problems arising from student employment could adequately be dealt with and solved.

Having worked in their professions for an average of nearly two decades, our respondents have witnessed the changes in students' lifestyle. Apart from a weekly 8-10 h of teaching, academics also have administrative and other tasks to complete. Due to the nature of seminars, and other practical activities within the faculty, academics have the opportunity to get to know their students. They reported being on good terms with their students, who often confided in them. It was from these conversations that academics learnt about their students' work. Moreover, respondents were able to give a close approximation of the prevalence of student employment, which corresponded to statistical data. Academics pointed out that students had typical student jobs offered by student job centers, and these were not related to their study. Faculty members also seemed to be aware of the reasons students took up jobs. Their answers also confirmed the results of previous stages of our research (student surveys and interviews in student job centers), namely that the main purpose of student employment was the improvement of financial situation as opposed to taking part in professional training and gaining work experience in one's field.

Academics also noted that students' academic performance and activity were negatively influenced by work and that work might even cause conflict among students. The first telling signs of a student being employed are being late for classes or their high absence rate. Absence leads to further problems. Firstly, there is a limited number of excused absences and this is taken seriously, especially in the case of practical classes and seminars. Secondly, students have to make up for their absences. Thirdly, if they exceed the number of excused absences, their lecturers find themselves in a dilemma whether to 
treat them more favorably as compared to students who do not work. Academics try to do their best in order to solve these problems. Some of the university teachers do not take absences too seriously, others prefer to extend deadlines or make teaching materials available for those who missed classes. These solutions are most efficient if students cooperate with their teachers and let them know in advance that problems caused by work might arise.

"It mostly surfaces in the number of absences; however, students do not exceed the number of the excused absences, the rules apply to everyone. There are no exemptions. I don't mind; on the contrary, I highly appreciate students who try to get by and this way help their parents. Nonetheless, it causes tension within the group. Their peers do not always tolerate that they are not treated equally. It can become unpleasant if someone, for example, has four absences instead of three. You let them get away with it because you know it is because of their social status. There are students who do not show up for class at 8 a.m. because they are lying drunk in the hostel. In these cases I usually warn them after their second or third absence to prevent further ones... Students look at the number but I look at what's behind it ... This might cause problems within a group." (Faculty member, University of Debrecen)

A more serious negative consequence of student employment is skipping exams or consultations. As it turned out from the interviews, students were sometimes unable to attend tests and exams because of their work. This disrupts the entire process of student assessment, which is an essential part of one's studies. These absences can hardly, if at all, be tolerated by academics.

"If someone misses too many classes, I often help them and share the lessons we covered in class, and then they have to report on it. Extra work? I also did that. We always make it clear in advance that postponing is accepted if something unexpected comes up. Otherwise, I try to be consistent and treat everybody the same way. Yet if someone cannot hand in the paper on time for some reason, they must let me know beforehand. When it comes to exams, however, I don't make allowances for work; the rules apply to everyone." (Faculty member, University of Nyíregyháza)

There is a general conviction that employment has a negative effect on student outcome, performance and activity. We asked academics if they had witnessed any positive effects of term-time student work. Opinions on this issue were divided. Some of the teachers pointed out students who work and achieve good results in their study, and are active in class, while others highlighted the negative effects on academic performance. They claimed that they noticed the poorer performance of certain students, especially if they were not aware of their employment. They did not judge problematic students; however, they consider there is a need for a compromise in this respect.

"She is always very active in class when she is present. This is how she tries to compensate for her absences. Students who work are obviously more mature. I think they can appreciate many things much more than those who don't work. This is especially true of those who provide not only for themselves but also for their families. I know of such cases as well." (Faculty member, University of Nyíregyháza)

"It is not self-evident. Similarly to students in correspondence courses, they often try to compensate for the fact that they work, and therefore they perform well." (Faculty member, University of Debrecen)

Faculty members expressed their views on how student employment and higher education could be brought closer to each other. Opinions differed but they all agreed that student employment is to be encouraged, especially if students are forced to work because of their poor financial situation. They also considered that higher education institutions should play a more important role in student employment. The most favored option, however, was for students to have jobs which would not only provide an income but also work experience in their field of study. The way universities could promote this is by the introduction of individual schedules or cooperation with companies, internship providers 
and student job centers. This would require the restructuring of the curriculum and an innovative attitude. Our respondents also put forward the idea of offering on-campus jobs to students, which could be beneficial in many ways.

\section{Conclusions}

In our research we attempted to present the characteristics of student work, as the entry of students in the labor market is becoming a more and more widespread phenomenon. Our sample consisted of students from two universities in Hungary, the University of Debrecen and the University of Nyíregyháza. We used qualitative methods to reveal the traits of student employment in the region. Structured individual interviews were conducted with 23 students doing regular paid work, and with 7 professors at the University of Debrecen and the University of Nyíregyháza. Including student job centers in our qualitative research was a novelty. Having analyzed students' and academics' opinions on student work, it can be concluded that employment-requiring sacrifice on the part of students-has become an essential part of students' lives in Hungary. It is meant to facilitate young people's independence and somewhat relieve families of their financial burdens. Our respondents' reasons for working were predominantly financial, although many reported that gaining work experience, even in areas not related to their studies, was an important consideration. In Hungary there are less on-campus work opportunities, and many of the jobs offered off campus are strenuous and not related to students' field of study. Since job centers in Hungary are companies, they are not interested in offering jobs related to students' field of study. Their primary goal is to employ students and they are not interested in reducing dropout rates. Job centers do not provide information on the risks of student employment. Interviewees' responses also confirmed previous study result, i.e. it is very important to inform students about job opportunities. There are universities which offer jobs to their students (Astin 1993; Pascarella et al. 1998). Another important aspect of our research is that students should learn how to keep the balance between work and study related responsibilities. Students unanimously agree that the best solution would be to have a job related to their field of study. The relationship between teachers and students should also undergo some changes. Academics believe that student employment should be encouraged; however, they also point out that jobs should be related to students' field of study. Collaboration between universities and student job centers could also be a solution. University teachers note that higher education institutions should undertake a more active role in student employment and should support students who work. This might ask for the introduction of individual curricula, cooperation with companies or job center, and teachers' supportive attitude. At present, it is not easy to assess the negative impact student employment might have on academic performance. However, the results of our research show that employment plays an important role in student dropout rates.

The results of the present study should not be generalized to all students who are employed. Further studies are needed to determine the causal relationship between social status and student employment. We are aware that the research needs to be expanded and interviews should be conducted with students coming from different socio-economic backgrounds. The quantitative part of our research is work in progress.

Author Contributions: All authors discussed the results and implications and commented on the manuscript at all stages.

Funding: Project No. 123847 has been implemented with the support provided from the National Research, Development and Innovation Fund of Hungary, financed under the K_17 funding scheme.

Acknowledgments: This research was supported through the New National Excellence Program of the Ministry of Human Capacities.

Conflicts of Interest: The funders had no role in the design of the study; in the collection, analyses, or interpretation of data; in the writing of the manuscript, or in the decision to publish the results. 


\section{References}

Astin, Alexander W. 1993. What Matters in College: Four Critical Years Revisited. San Francisco: Jossey-Bass.

Baffoe-Bonnie, John, and Lonnie Golden. 2007. Work-Study: Time Use Trade Offs, Student Work Hours and Implications for Youth Employment Policy. Available online: http://www.atususers.umd.edu/wip2/papers_ i2007/Golden.pdf (accessed on 3 June 2019).

Becker, Gary. 1994. Human Capital Revisited. In A Theoretical and Empirical Analysis with Special Reference to Education. Edited by Gary Becker. Chicago: The University of Chicago Press, pp. 15-28.

Bocsi, Veronika, Hajnalka Fényes, and Valéria Markos. 2017. Motives of volunteering and values of work among higher education students. Citizenship Social and Economics Education 16: 117-31. [CrossRef]

Bocsi, Veronika, Tímea Ceglédi, Zsófia Kocsis, Karolina Eszter Kovács, Klára Kovács, Anetta Müller, Katalin Pallay, Barbara Éva Szabó, Fruzsina Szigeti, and Dorina Anna Tóth. 2018. “A pedagógushallgatók késleltetett diplomaszerzése interjúk alapján." [The Discovery of the Possible Reasons for Delayed Graduation and Dropout in the Light of a Qualitative Research Study]. In Lemorzsolódás és Perzisztencia a Felsőoktatásban. Edited by Gabriella Pusztai and Fruszina Szigeti. Debrecen: Debreceni Egyetemi Kiadó, pp. 63-91.

Canny, Angela. 2002. Flexible Labour? The Growth of Student Employment in the UK. Journal of Education and Work 15: 277-301. [CrossRef]

Darmody, Merike, and Emer Smyth. 2008. Full-time students? Term-time employment among higher education students in Ireland. Journal of Education and Work 21: 349-62. [CrossRef]

Derényi, András. 2015. Bizonyítékokra alapozott kormányzás és a kommunikáció képzés. [Evidence-based Governance and Communication Training]. Jelkép, 1-21. [CrossRef]

Gáti, Annamária, and Péter Róbert. 2011. Munkavállalás a tanulás mellett: kényszerúség vagy befektetés? [Working during Studies: Constraint or Investment?]. In Frissdiplomások. Edited by Garai Orsolya and Veroszta Zsuzsanna. Budapest: Educatio Társadalmi Szolgáltató Nonprofit, pp. 93-109.

Gouvias, Dionyssios, and C. Vitsilakis-Soroniatis. 2005. Student employment and parental influences on educational and occupational aspirations of Greek adolescents. Journal of Education and Work 18: 421-49. [CrossRef]

Hovdhaugen, Elisabeth. 2015. Working while studying: the impact of term-time employment on dropout rates. Journal of Education and Work 28: 631-51. [CrossRef]

Kasler, Jonathan, Leehu Zysberg, and Nofar Harel. 2017. Hopes for the future: demographic and personal resources associated with self-perceived employability and actual employment among senior year students. Journal of Education and Work 30: 881-92. [CrossRef]

Kocsis, Zsófia. 2017a. A hallgatói munkavállalás jellemzői a debreceni és a nyíregyházi egyetemisták körében. [The Student Employments Characteristics of The University of Debrecen University and The University of Nyíregyháza]. PedActa 7: 81-89.

Kocsis, Zsófia. 2017b. Diákként a munkaerőpiacon. A hallgatói munkavállalás jellemzői a debreceni egy nyíregyházi egyetemisták körében. [As a student in the labor market. the student employment's characteristics of the University of Debrecen and the college of Nyíregyháza]. In Diáktudósok. Edited by Szirmai Éva. Szeged: Szegedi Egyetemi Kiadó, pp. 57-73.

Kóródi, Márta. 2007. Munkaértékek vizsgálata két felsőoktatási intézményben. [Examining Work Values in Two Higher Education Institutions]. Educatio 16: 311-22.

Markos, Valéria. 2014. Egyetemisták a munka világában. [Students in the World of Work]. In Campus-Lét a Debreceni Egyetemen Ifjúságszociológiai Tanulmányok. Edited by Fényes Hajnalka and Szabó Ildikó. Debrecen: Debreceni Egyetemi Kiadó, pp. 109-133.

Masevičiūtè, Kristina, Vaida Šaukeckienè, and Eglè Ozolinčiūtè. 2018. Eurostudent VI. Combining Studies and Paid Jobs. Available online: http://www.eurostudent.eu/download_files/documents/TR_paid_jobs.pdf (accessed on 3 June 2019).

McCoy, Selina, and Emer Smyth. 2004. At Work in School. Dublin: ESRI/Liffey Press.

Moreau, Marie-Pierre, and Carole Leathwood. 2006. Balancing paid work and studies: Working (-class) students in higher education. Studies in Higher Education 31: 23-42. [CrossRef]

Nagy, Mária. 2006. A Tanárok "Hangja", Osztálytermi Viselkedésük. Budapest: Országos Közoktatási Intézmény.

Pascarella, Ernest T., and Patrick T. Terenzini. 2005. How College. Affects Students: A Third Decade of Research. San Francisco: John Wiley. 
Pascarella, Ernest T., Marcia I. Edison, Amaury Nora, Linda Serra Hagedorn, and Patrick T. Terenzini. 1998. Does Work Inhibit Cognitive Development during College? Educational Evaluation and Policy Analysis 20: 75-93. [CrossRef]

Perna, Laura. 2012. Understanding the Working College Student New Research and Its Implications for Policy and Practice. Sterling: Stylus Publishers.

Pusser, Brian. 2012. Of a mind to labor: Reconceptualizing student work and higher education. In Understanding the Working College Student: New Research and Its Implications for Policy and Practice. Edited by Laura Perna. Sterling: Stylus Publishers, pp. 134-55.

Pusztai, Gabriella. 2011. A Láthatatlan Kéztől a Baráti Kezekig. Hallgatói Értelmező Közösségek a Felsőoktatásban. [From the Invisible Hand to the Hands of Friends. Student Interpreting Communities in Higher Education]. Budapest: Ujj Mandátum Kiadó.

Pusztai, Gabriella. 2014. The Effects of Institutional Social Capital on Students' Success in Higher Education. Hungarian Educational Research Journal 4: 68-83. [CrossRef]

Pusztai, Gabriella. 2015. Pathways to Student Success in Higher Education. Rethinking the Social Capital Theory in the Light of Institutional Diversity. Frankfurt am Main: Peter Lang.

Pusztai, Gabriella, and Tamás Kozma. 2009. Kié a doktori iskola? Educatio 18: 64-75.

Riggert, Steven C., Mike Boyle, Joseph M. Petrosko, Daniel Ash, and Carolyn Rude-Parkins. 2006. Student Employment and Higher Education: Empiricism and Contradiction. Review of Educational Research 76: 63-92. [CrossRef]

Roshchin, Sergey, and Victor Rudakov. 2017. Patterns of student employment in Russia. Journal of Education and Work 30: 314-38. [CrossRef]

Stiburek, Šimon, Ales Vlk, and Vaclav Švec. 2017. Study of the success and dropout in the higher education policy in Europe and V4 countries. Hungarian Educational Research Journal 7: 43-56.

(C) 2019 by the authors. Licensee MDPI, Basel, Switzerland. This article is an open access article distributed under the terms and conditions of the Creative Commons Attribution (CC BY) license (http://creativecommons.org/licenses/by/4.0/). 